\title{
PENGEMBANGAN MEDIA PEMBELAJARAN PRAKTIKUM KIMIA MENGGUNAKAN CAMTASIA STUDIO 8 DI SMA NEGERI 1 SIPIROK TAHUN AJARAN 2016 - 2017
}

\author{
Viva Mulyana'), Abubakar'), Sahlan Tuah²) \\ ${ }^{1)}$ Pendidikan Kimia, FKIP Universitas Muhammadiyah Tapanuli Selatan \\ ${ }^{2}$ Pendidikan Biologi, FKIP Universitas Muhammadiyah Tapanuli Selatan \\ aboe@um-tapsel.ac.id,
}

\begin{abstract}
This study to design, construct and test the feasibility of the learning media use Camtasia Studio 8 and to get information whether by developing learning media of chemistry practicum using Camtasia Studio 8 more effectively and efficiently. The results of the research are: (1) The process of making media using Camtasia Studio 8 includes identification of competence, scriptwriting, media design, animation making, audio making, program testing techniques, expert review, repair, final product. Based on the assessment of media experts, the learning media using Camtasia Studio 8 deserves to be used as a learning video media. (2) The data of the lecturers' lecture in terms of the feasibility aspects of the contents of the first lecturer with a score of 33 and the second lecturer get a score of 27 . The language eligibility of the first lecturer score of 31 and the second lecturer get a score of 27. Feasibility of presentation of the first lecturer with a score of 13 and lecturers both received a score of 11. (3) Assessment of the first subject teachers if viewed from the aspect of eligibility of the content with the score obtained 31 as well as from the second subject teachers. The language eligibility of the first subject teacher scores 30 , while the second subject teacher scores 27 . The eligibility of the presentation of the first and second subject teachers also earns the same score of 13. Overall, the average overall score of this learning video medium is 4.13 .
\end{abstract}

Keywords: Development of Chemical Practical Learning Media, Camtasia Studio 8, Solubility and Solubility Times.

\begin{abstract}
Abstrak
Penelitian ini bertujuan untuk merancang, membuat dan menguji kelayakan media pembelajaran menggunakan Camtasia Studio 8 dan untuk mendapatkan informasi apakah dengan pengembangan media pembelajaran praktikum kimia menggunakan Camtasia Studio 8 lebih efektif dan efisien. Hasil penelitian yang diperoleh adalah: (1) Proses pembuatan media menggunakan Camtasia Studio 8 meliputi: identifikasi kompetensi, penulisan naskah, merancang media, pembuatan animasi, pembuatan audio, teknik pengujian program, tinjauan ahli, perbaikan, produk akhir. Berdasarkan penilaian dari ahli media, media pembelajaran menggunakan Camtasia Studio 8 layak digunakan sebagai media video pembelajaran. (2) Data penilaian dari dosen ditinjau dari aspek kelayakan isi dari dosen pertama dengan skor 33 dan dosen kedua mendapatkan skor 27. Kelayakan bahasa dari dosen pertama skor sebesar 31 dan dosen kedua mendapatkan skor 27. Kelayakan penyajian dari dosen pertama dengan skor 13 dan dosen kedua mendapat skor sebasar 11. (3) Penilaian guru mata pelajaran pertama jika ditinjau dari aspek kelayakan isi dengan skor yang didapat 31 begitu juga dari guru mata pelajaran kedua. Kelayakan bahasa dari guru mata pelajaran pertama mendapat skor 30, sementara guru mata pelajaran kedua dengan skor 27. Kelayakan penyajian dari guru mata pelajaran pertama dan kedua juga memperoleh skor yang sama yaitu 13. Secara keseluruhan diperoleh skor rata-rata keseluruhan media video pembelajaran ini sebesar 4,13.
\end{abstract}

Kata Kunci: Pengembangan Media Pembelajaran Praktikum Kimia, Camtasia Studio 8, Kelarutan dan Hasil Kali Kelarutan.

8 | PeTeKa (Jurnal Penelitian Tindakan Kelas dan Pengembangan Pembelajaran) 


\section{PENDAHULUAN}

Pelajaran kimia termasuk salah satu bidang studi IPA yang dipelajari di sekolah. Dalam paradigma baru proses pembelajaran memberi tuntutan kepada guru untuk meningkatkan peranan dan kompetensinya, karena proses pembelajaran dan hasil belajar sebagian besar ditentukan oleh peranan dan kompetensi guru. Guru yang kompeten akan mampu mengelola kelasnya sehingga hasil belajar siswa berada pada tingkat yang optimal.

Pemahaman siswa terhadap materi ajar akan lebih efektif jika ia tidak hanya memperoleh konsepnya, tetapi ia juga harus mampu menemukan konsep itu sendiri. Dimyati (2009) mengemukakan bahwa belajar yang baik adalah belajar melalui pengalaman langsung. Dengan pengalaman langsung siswa tidak sekedar mengamati tetapi juga menghayati, berbuat sendiri, dan bertanggung jawab atas hasilnya. Dan itu dapat diperoleh melalui praktikum atau eksperimen.

Berdasarkan silabus SMA sederajat dalam setiap materi kimia, kegiatan pembelajaran dituntut untuk melakukan percobaan atau praktikum. Namun, kegiatan pembelajaran ini jarang dilakukan, disamping jumlah peserta didik tidak mendukung juga alat dan bahan yang terbatas. Oleh karena itu, untuk meningkatkan kualitas pembelajaran, penggunaan media berbantuan komputer merupakan salah satu alternatif yang tepat, karena dengan memilih dan menerapkan media pembelajaran yang tepat, dapat mempengaruhi pemahaman dan pengetahuan siswa sehingga siswa dapat menerapkan dalam kehidupannya seharihari.

Mempelajari materi dalam kimia tidak cukup hanya dengan membaca buku dan menghapal rumus saja apa lagi materi kimia terbilang bersifat abstrak, maka diperlukan media yang berbasis Komputer. Para peneliti telah menemukan bahwa ada berbagai cara siswa mudah memproses informasi. Sebagian mudah memproses informasi visual, sebagian lain lebih merasa senang atau lebih mudah bila ada suara, dan sebagian lain akan mudah memahami jika menggunakan informasi tertulis. Hal ini sesuai dengan penelitian yang dilakukan Wagiran (2008) dengan komputer dapat dibuat sebuah pembelajaran yang menarik karena hal tersebut membuat peserta didik lebih termotivasi dan senang belajar sehingga berdampak pada meningkatnya hasil belajar dari peserta didik.

Berdasarkan permasalahan di atas peneliti bermaksud untuk membuat dan merancang media pembelajaran sehingga hasil belajar siswa meningkat yaitu dengan mengembangkan media pembelajaran tentunya menggunakan program camtasia studio 8. Media berbasis komputer seperti camtasia adalah media yang dapat menampilkan visualisasi pembelajaran sehingga tidak terjadi kesalahpahaman antara guru dengan siswa. Dengan media disamping menarik, juga dapat mempercepat pemahaman siswa tentang ilustrasi dan strukturisasi data yang berefek pada peningkatan hasil belajar siswa.

Dengan pemanfaatan software camtasia studio 8 media pebelajaran mampu mengefektifkan waktu belajar dan penyampaian materi dapat lebih menarik dan jelas. Camtasia adalah software yang diinstalkan ke komputer (laptop) sehingga dapat merekam presentasi menjadi video berbentuk flim pendek.

Berkaitan dengan ini, menurut Setiawan (2011) Camtasia adalah software (perangkat lunak) yang dikembangkan oleh TechSmith Coorporation yang dapat merekam semua aktifitas yang ada pada desktop komputer. Selain itu, software ini bisa kita manfaatkan untuk membuat media pembelajaran berbasis multimedia dan elearning. Kemampuan utama camtasia adalah merekam aktivitas layar desktop secara penuh atau sebagaian, dan menyimpan hasil rekaman ke dalam format video. Menurut Retno, dkk. (2014) video Camtasia merupakan model pembelajaran yang valid, praktis, dan efektif serta sesuai 
kurikulum 2013. Sedangkan menurut Setyorini, $d k k$. (2016) Media video merupakan salah satu alternatif dari media pembelajaran yang bias digunakan dalam mengajar. Salah satu program untuk mengolah video itu adalah Camtasia Studio 7. Dimana dengan penggunaan program ini kita bisa membuat video presentasi yang ada pada layar (screen) komputer. Dengan menggunakan slide presentasi dan mengubahnya dalam bentuk video dengan menyisipkan beberapa video ataupun gambar biasa memudahkan untuk digunakan sebagai media pembelajaran di kelas.

\section{METODE}

Penelitian ini merupakan jenis penelitian dan pengembangan (Research and Development). Menurut Sugiyono (2013:407) penelitian ini merupakan suatu penelitian yang dimaksud untuk menghasilkan produk tertentu dan menguji keefektifan produk tersebut. Untuk menghasilkan produk tertentu digunakan penelitian yang bersifat analisis kebutuhan dan untuk menguji keefektifan produk tersebut diperlukan penelitian untuk menguji keefektifan produk tersebut.

Penelitian ini dilaksanakan dalam beberapa tahapan. Tahap pertama adalah pengembangan yaitu merancang dan membuat serta menguji media pembelajaran tersebut untuk mengetahui kelayakannya. Dan tahap selanjutnya menggunakan media pembelajaran tersebut dengan tujuan untuk mendapatkan informasi apakah dengan pengembangan media pembelajaran praktikum kimia menggunakan camtasia studio 8 lebih efektif dan efisien dibandingkan pembelajaran yang biasa diterapkan guru.

Teknik pengumpulan data dalam penelitian ini adalah Angket, diberikan untuk menilai kelayakan dari media video pembelajaran dengan menggunakan program camtasia studio 8 . Hasil angket diberi skor dalam bentuk ceklist $(\sqrt{ })$. Penyerahan angket kelayakan media terdiri dari 3 kriteria penilaian yaitu kelayakan materi, kelayakan bahasa dan kelayakan penyajian dengan indikator berbeda, Pernyataan dan kolom jawaban memiliki 5 alternatif pilihan yaitu Sangat Sesuai (SS), Sesuai (S), Biasa Saja (BS), Tidak Sesuai (TS), Sangat tidak sesuai (STS). Nilai kelayakan media dapat diperoleh dari pengisian angket yang diisi oleh 4 responden yang terdiri dari 2 orang dosen ahli dan 2 orang guru mata pelajaran kimia. Data yang diperoleh dari hasil pengisian angket berupa data kualitatif dan kuantitatif. Data kuantitatif berasal dari angket berupa nilai rata - rata, penilaian terhadap media terdiri dari 3 standar penilaian yaitu, 7 item kelayakan isi, 7 item kelayakan bahasa dan 3 item kelayakan penyajian. Sementara data kualitatif diperoleh dari saran responden. Saran yang diberikan digunakan sebagai bahan pertimbangan untuk memperbaiki media yang dikembangkan.

Sebelum media diterapkan, Pengembangan media pembelajaran menggunakan camtasia studio 8 diawali dari identifikasi kompetensi yang harus dikuasai siswa dalam mata pelajaran kimia dengan materi kelarutan dan hasil kali kelarutan, hingga terbentuk media belajar berupa video pembelajaran, tahap-tahap tersebut secara rinci adalah:

(1)Identifikasi kompetensi

Tahap pertama dari pembuatan media adalah identifikasi kompetensi berupa pemilihan materi dengan indikator yang akan dibahas dan perumusan program yang akan dibuat, hasil-hasil yang akan dicapai, serta skenario pembuatan.

(2)Penulisan naskah

Dalam penulisan naskah langkah yang dilakukan adalah menuangkan dalam bentuk konsep-konsep materi yang sesuai dengan silabus pembelajaran kimia kelas XI SMA di kertas HVS sehingga proses produksi lebih terstruktur dan teratur. Materi yang dimaksud disini adalah kelarutan dan hasil kali kelarutan, konsep-konsep yang berkaitan dalam pokok bahasan 
kelarutan dan hasil kali kelarutan tersebut

(3)Merancang media

Merancang media video pembelajaran yang dapat menjelaskan konsep-konsep dalam pokok bahasan kelarutan dan hasil kali kelarutan. Setelah penulisan yang dibuat di kertas HVS dianggap sesuai dengan konsep yang akan ditampilkan, langkah selanjutnya membuat video pembelajaran mengunakan Powerpoint dan tentunya dengan menggunakan Camtasia studio 8. Dalam media pembelajaran ini terdapat pembukaan video, konsep, suara, gambar yang bergerak, musik, dan beberapa video berkaitan dengan materi.

(4)Pembuatan animasi

Animasi yang dibuat disesuaikan dengan tema, pokok materi, serta kemudahan untuk dipahami. Dengan animasi diharapkan dapat menimbulkan suasana menyenangkan dalam belajar.

(5)Pembuatan Audio

Pada langkah ini mulai merancang musik pendukung serta mengisi suara untuk animasi. Suara-suara yang digunakan diusahakan mampu mendukung suasana belajar sehingga harus dihindari kesan berisik, gaduh dan mengagetkan.

(6)Teknik Pengujian Program

Tahap pertama pengujian adalah menjalankan media pembelajaran menggunakan camtasia studio 8 yang sudah ada dalam format MP4. Semua pengujian yang dilakukan untuk memastikan semua tombol dapat berfungsi dengan baik sesuai dengan desain yang dibuat. Setelah semua unsur lengkap maka semua komponen dipadukan sesuai dengan rancangan program. Dari tahapan ini terbentuklah produk awal berupa video pembelajaran pada materi kelarutan dan hasil kali kelarutan.
(7)Tinjauan ahli

Produk awal ini kemudian diperiksa oleh 4 orang ahli yang terdiri dari 2 orang dosen ahli media pembelajaran dan 2 orang guru mata pelajaran kimia. Ahli tersebut mencoba menjalankan program kemudian diminta masukan dan kritiknya melalui angket yang diberikan. Uji ahli ini dilakukan untuk mengetahui kelayakan media berupa video pembelajaran pada materi kelarutan dan hasil kali kelarutan.

\section{HASIL DAN PEMBAHASAN}

\section{Hasil Penilaian Dosen Terhadap Media Pembelajaran}

Penilaian terhadap media dari dosen diperoleh bahwa media menarik dan dapat menumbuhkan motivasi siswa, dan saran dari dosen berupa ada baiknya media yang disajikan dimuat dengan isi yang sistematis dan produktif. Penilaian dari dosen terhadap media video pembelajaran tiap standar penilaian disajikan dalam tabel 1 .

Data penialaian dari dosen ditinjau dari aspek (1) kelayakan isi dari dosen pertama dengan skor yang didapat yaitu 33 dengan rata-rata sebesar 4,71, sementara penilaian dari dosen kedua mendapatkan skor 27 dengan rata-rata 3,85. (2) kelayakan bahasa dari dosen pertama didapat skor sebesar 31 dengan rata-rata 4,42, dan penilaian dari dosen kedua mendapatkan skor 27 dengan rata-rata sebesar 3,85. (3) kelayakan penyajian dari dosen pertama dengan skor yang didapat 13 dengan ratarata sebesar 4,33, dan penilaian dari dosen kedua mendapat skor sebasar 11 dengan rata-rata 3,67. Secara keseluruhan penilaian terhadap media dari dosen memperoleh rata-rata 4,17 .

Lebih jelasnya penilaian dari dosen tiap standar penilaian terlihat pada gambar 1. 
PeTeKa (Jurnal Penelitian Tindakan Kelas dan Pengembangan Pembelajaran)

Vol 1 No 1 Tahun 2017 Hal 8-14

Tabel 1: Data Responden Angket Media Dari Dosen

\begin{tabular}{lcccc}
\hline \multirow{2}{*}{ Kode responden } & \multicolumn{4}{c}{ Standar penilaian } \\
& Kelayakan isi & Kelayakan bahasa & Kelayakan penyajian & Jlh \\
\hline $\mathrm{DA}_{\mathrm{I}}$ & 4,71 & 4,42 & 4,33 & \\
$\mathrm{DA}_{\mathrm{II}}$ & 3,85 & 3,85 & 3,67 & \\
jumlah & 8,56 & 8,27 & 8,00 & \multirow{2}{*}{4,13} \\
Rata-rata & 4,28 & 4,14 & 4,00 & Layak \\
Kriteria & Sangat layak & Layak & layak & \\
\hline
\end{tabular}

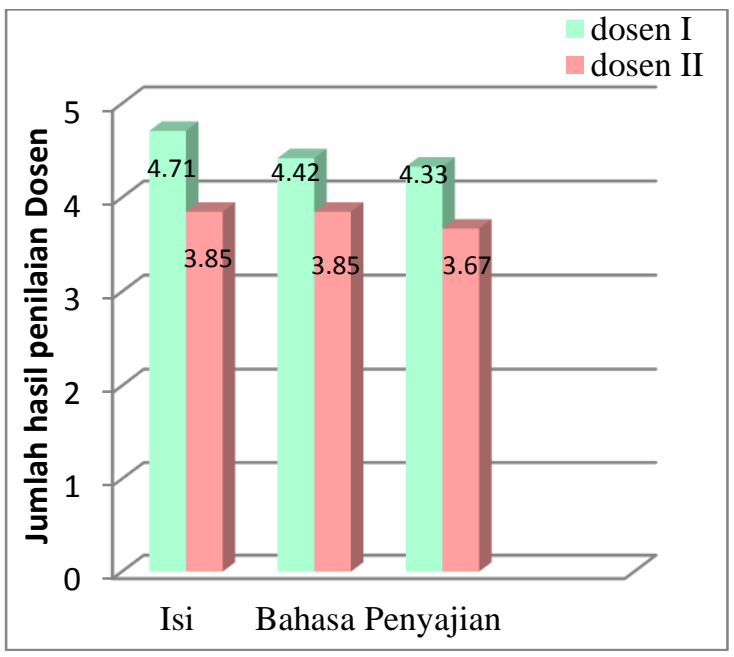

Gambar 1: Grafik Data Responden Angket Media Dari Dosen

\section{Hasil Penilaian Guru Mata Pelajaran Terhadap Media Pembelajaran}

Penilaian terhadap media dari guru diperoleh bahwa media menarik dan dapat menumbuhkan motivasi siswa, dan saran dari dosen berupa ada baiknya media yang disajikan dimuat dengan isi yang sistematis dan produktif. Penilaian dari guru mata pelajaran terhadap media video pembelajaran menggunakan camtasia studio 8 berdasarkan angket yang diberikan disajikan dalam tabel 2.

Penilaian guru mata pelajaran pertama jika ditinjau dari aspek (1) kelayakan isi dengan skor yang didapat 31 memperoleh rata-rata sebesar 4,43 begitu juga dari guru mata pelajaran kedua. (2) kelayakan bahasa dari guru mata pelajaran pertama mendapat skor 30 dengan rata-rata 4,29 , sementara guru mata pelajaran kedua dengan skor 27 mempunyai rata-rata sebesar 3,86. (3) kelayakan penyajian dari guru mata pelajaran pertama dan kedua juga memperoleh skor yang sama yaitu 13 dengan rata-rata 4,33. Secara keseluruhan penilaian terhadap media dari guru mata pelajaran memperoleh rata-rata 4,11 .

Lebih jelasnya penilaian dari guru mata pelajaran tiap standar penilaian terlihat pada gambar 2 .

Tabel 2: Data Responden Angket Media Dari Guru Mata Pelajaran

Standar penilaian

Kode responden

\begin{tabular}{lcccc} 
& Kelayakan isi & Kelayakan bahasa & Kelayakan penyajian & Jlh \\
\hline GMP I $^{\text {GMP }}$ II & 4,43 & 4,29 & 3,33 & \\
jumlah & 4,43 & 3,86 & 4,33 & \\
Rata-rata & 8,86 & 8,15 & 7,66 & \\
Kriteria & 4,43 & 4,07 & 3,83 & 4,11 \\
& Sangat layak & Layak & layak & Layak \\
\hline
\end{tabular}


Viva Mulyana, dkk. Pengembangan Media Pembelajaran Praktikum Kimia...

Tabel 3: Penilaian Media Secara Keseluruhan Dari Ahli

\begin{tabular}{lcccc}
\hline \multirow{2}{*}{ Kode responden } & \multicolumn{4}{c}{ Standar penilaian } \\
& Kelayakan isi & Kelayakan bahasa & Kelayakan penyajian & Jlh \\
\hline DA & 4,28 & 4,14 & 4,00 & \\
GMP & 4,43 & 4,07 & 3,83 & \\
\hline jumlah & 8,71 & 8,21 & 7.83 & \multirow{2}{*}{4,13} \\
Rata-rata & 4,36 & 4,11 & 3.92 & Layak \\
Kriteria & Sangat layak & Layak & layak & \\
\hline
\end{tabular}

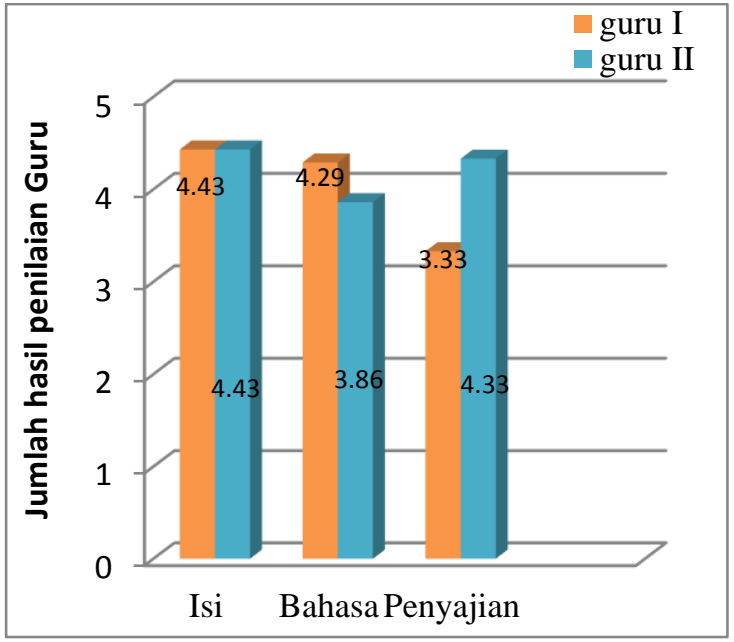

Gambar 2: Grafik Data Responden Angket Media Dari Dosen

Berdasarkan kedua data diatas dapat disimpulkan penilaian dari ahli disajikan pada tabel 3.

Perbandingan penilaian antara dosen ahli dan guru mata pelajaran terihat pada gambar 3 .

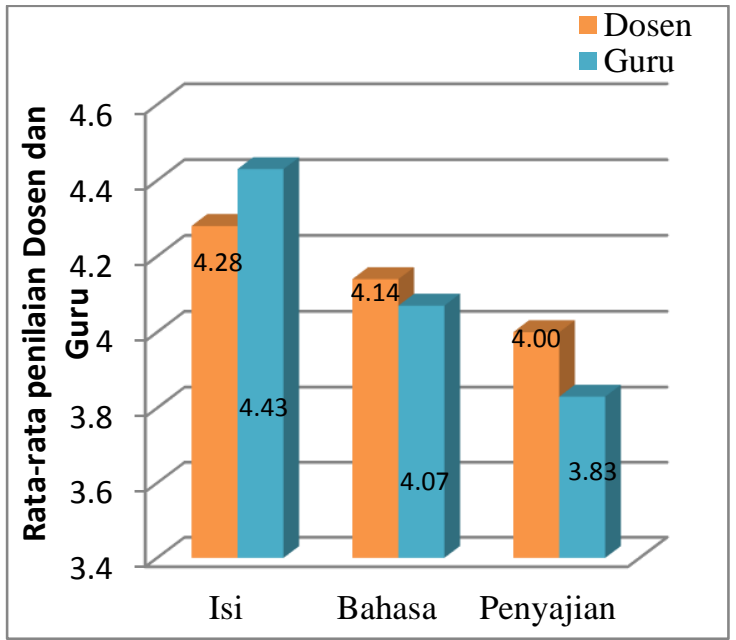

Gambar 3: Grafik Penilaian Media Secara Keseluruhan Dari Ahli
Berdasarkan data yang disajikan pada Tabel 3 tersebut, diperoleh skor ratarata keseluruhan media video pembelajaran ini sebesar 4,13 sehingga dapat dikategorikan layak digunakan sebagai media video pembelajaran di kelas pada materi kelarutan dan hasil kali kelarutan.

\section{SIMPULAN}

Proses pembuatan media berbantuan komputer meliputi: identifikasi kompetensi, penulisan naskah, merancang media, pembuatan grafis, pembuatan animasi, pembuatan audio, teknik pengujian program, tinjauan ahli, perbaikan, produk akhir.

\section{DAFTAR PUSTAKA}

Dimyati dan Mudjiono. (2009). Belajar dan Pembelajaran. Jakarta: Rineka Cipta.

Retno, Eli Widoyo., Mardiyana. dan Tri Atmojo Kusmayadi. (2014). Pengembangan Model Pembelajaran Group Investigation (Gi) Berbantu Video Camtasia Pada Materi Peluang Untuk Siswa Sma/Ma Negeri Kabupaten Cilacap Tahun Pelajaran 2013/2014. Jurnal Elektronik Pembelajaran Matematika. Vol.2, No.5.

Setiawan, Candra. (2011). Pembuatan Video Materi Ajar dengan Camtasia. Fakultas Ilmu Komputer Universitas Sriwijaya: Universitas Sriwijaya. 
PeTeKa (Jurnal Penelitian Tindakan Kelas dan Pengembangan Pembelajaran)

Vol 1 No 1 Tahun 2017 Hal 8-14

Setyorini, Evi Sulis., Isna Tiyaswati., Lisa Faradilla., Rinta Dian Pratiwi. (2016). Pembuatan Video Pembelajaran Menggunakan Camtasia Studio 7 sebagai Media Pembelajaran Fisika pada Materi Hukum Newton. Seminar Nasional Pendidikan dan Saintek 2016. ISSN: 2557-533X.
Sugiono. (2013). Metode Penelitian Pendidikan Pendekatan Kuantitatif, Kualitatif, dan $R \& D$. Bandung: Alfabeta.

Wagiran. (2008). Pengembangan Media Berbantuan Komputer Sebagai Upaya Meningkatkan Kualitas Perkuliahan Metrologi. Jurnal Kependidikan Vol. 38, No. 2. 